Article

\title{
A Sustainable Innovation-Additional Services for Products Based on Personalised Customer Value
}

\author{
Shaofei Jiang ${ }^{1}$, Di Feng ${ }^{1}$ and Chunfu Lu ${ }^{2, *}$ \\ 1 College of Mechanical Engineering, Zhejiang University of Technology, Hangzhou 310000, China; \\ jsf75@zjut.edu.cn (S.J.); $1111402119 @ z j u t . e d u . c n$ (D.F.) \\ 2 Industrial Design Institute, Zhejiang University of Technology, Hangzhou 310000, China \\ * Correspondence: cflu@zjut.edu.com; Tel.: +86-571-85290188
}

Received: 27 November 2018; Accepted: 19 March 2019; Published: 23 March 2019

\begin{abstract}
As a sustainable innovation, offering additional services for products (ASP) is rapidly emerging as an increasingly important consideration for manufactories. Although additional services can increase enhance product utility, there is no guarantee that they will be accepted by customers. This may lead to a waste of product and service resources. Customer acceptance is a prerequisite for sustainability. However, existing service evaluation methods do not support the evaluation of customer acceptance of ASP prior to implementation. We confirmed that customer value can be used to evaluate customer acceptance of ASP based on the conclusion that this factor plays a decisive role in customer acceptance and customer value can be used to evaluate products and services. Then we establish an evaluation model to measure the difference in customer value between products with and without ASP. Utility, input, and supply-demand coefficient were used to quantitatively describe the personalised customer value of customer segments. This approach supports manufacturers in the process of estimating customer acceptance of ASP prior to the allocation of service resources to the implementation of procedure. Using this model, manufactories can provide the most acceptable ASP for different customer groups with less service resources. Finally, the feasibility and effectiveness of the proposed method to measure customer acceptance were established based on the measurement of customer value of the ASP in the case of portable fire extinguishers.
\end{abstract}

Keywords: sustainable innovation; additional service for products; customer acceptance; customer value; evaluation model

\section{Introduction}

Sustainable innovation and design are not necessarily related to new technologies but to the rethinking of approaches to address the need for growth while reducing negative environmental and social impacts [1]. There has been a growing interest from academics, policy-makers and practitioners in a wider and holistic perspective of service innovation as a new promising "transcendent business logic" that fosters sustainability [2,3]. Service innovation has become a term that refers to innovation in diverse service situations, including the introduction of new services or incremental improvements to current services [4]. Manufacturers increasingly engage in service innovation, and as a result add services in combination with their products [5]. For example, Apple Inc. offers customers electronics and additional entertainment services, IBM provides computer-related products and technical services, and many high-end car companies provide $4 S$ services to their customers [6].

As a kind of service innovation, additional services for products (ASP) that fosters sustainability has become an increasingly important consideration for manufacturers [7-10]. ASP extends the functionality of products by considering of services as extensions of products [11]. Access to ASPs can support product function, increase the added value of the product, and satisfy customer needs [12-14]. 
As such, the substitution of tangible products with services can reduce the use of materials because services are inherently [15]. Therefore, this is an effective method for addressing the needs of customers using minimal materials and energy for the sustainable development of companies $[16,17]$.

However, some studies suggest that ASP may also have a negative impact on the environment, because the implementation of services can lead to the additional consumption of resources such as fuel, materials, or energy [18-20]. It may not be sustainable in any real sense, because unacceptable service leads to a waste of resources [21]. According to Raharjo, the cost of not having an accurate voice of customers is substantially large, since it determines all the subsequent downstream processes [22]. Mont proposed that service programs must develop organisational arrangements to ensure efficient use of resources [23]. Sampson indicated that firms must emphasise the selection, development and management of service innovation activities and features that focus directly on the customer [24]. The existing sustainable service innovation methods mainly focus on replacement, ownership, sharing, etc., but there is a lack of analysis of customer acceptance [25]. It is desirable for manufactures to have an accurate estimate of customer acceptance of ASPs prior to implementation.

In marketing, service-dominant logic highlights the need for a deeper understanding of the requirements of value customers with respect to services, rather than defining value from the manufacturers' perspective [26]. Customer value can be defined as the benefits and satisfaction that a firm can deliver to its customers [27]. The key dimensions of customer value drive customer behaviour: they reflect the criteria in the evaluation process [28]. Customer value has played the role of the antecedent of many behavioural outcomes, including patronage, re-patronage intention, customer satisfaction, and customer loyalty [29]. It is more sustainable for manufacturers to develop different implementation plans for different customer segments by evaluating customer acceptance of ASP, instead of the evaluation of customer satisfaction subsequent to implementation. In this report, we investigate the evaluation of customer acceptance of ASP by measuring customer value before significant resources are allocated to implementation.

In Section 2, the evaluation method of service quality is confirmed to be invalid for the measurement of customer acceptance. Customer value, which can be used to evaluate products and services, comes prior to and is conclusive for customer acceptance. On the basis of the above, the core point of this paper-that customer value can be measured to evaluate customer acceptance of ASP-is proposed. Section 3 presents the details of a method that considers utility, input and supply-demand coefficient to measure customer acceptance of ASP. Section 4 evaluates the feasibility and effectiveness of the proposed method by investigating the ASPs of portable fire extinguishers.

\section{Literature Review for Customer Acceptance and Customer Value}

An increasing number of scholars believe that customer acceptance has a great impact on the sustainability of service innovation, and services that are not accepted and purchased are not sustainable [30]. Herbig and Day look at customer acceptance of innovations and concluded that customer acceptance is the first and most important aspect of this process [31]. Therefore, we propose to evaluate whether ASPs is easy to be accepted by customers in order to ensure sustainability.

The most commonly known service evaluation method is SERVQUAL, which was developed by Parasuraman et al. [32]. This method, which is based on the expectation disconfirmation model, takes into account the relationship between expectations and outcomes [33,34]. Specifically, it evaluates service quality which is determined as the difference between the expectation and actual experience of the customer [35]. However, the expectation and perception of customers may be highly intermittent over time, so this model is not suitable for general industries and enterprises [36]. Moreover, customer acceptance includes the decision to purchase, try out or test a product which takes place before use [37]. The evaluation result generated by SERVQUAL is not applicable to customer acceptance because the evaluation before and after use differ significantly. In addition, the evaluation of the service cannot completely measure the customer's perception, because customers evaluate ASP by comparing the 
perception between products with or without ASP, instead of just the service [38]. Therefore, we confirm that the service evaluation method is not applicable to the evaluation of customer acceptance of ASP.

Chang and Dibb argued that customer value is preferential due to the fact that consumer's initial evaluation of value leads to emotional reactions (attitudes, subjective reactions) which drive behaviour and determine the act of customers [39]. Customer value is a customer's preference for and the evaluation of the attributes of a given product, functionalities, and results that facilitate the achievement of his or her goals in certain context of use [40]. Kashyap examined hotels as the research object and established that customer value can positively influence customers' purchase intention [41]. Customer value can directly influence the level of satisfaction and the purchasing behaviour of customers [42]. In conclusion, customer value plays a decisive role in customer acceptance.

Chan et al. considered customer value as a measure of product attractiveness and customer response. However, they focused on purchasing and repurchase behaviour, rather than acceptance [43]. Xing et al. proposed a sustainability-oriented value assessment model to support products and services development based on life cycle thinking. This method evaluates products and services based on customer value but lacks dynamic contrast between what customers expect and what customers experience [44]. Lee et al. proposed a method of evaluating products and services from the customers' perspective, addressing customers' acceptance of products and services by examining the context of the customers' decisions [38]. The customer value perception obtained in this method is derived from customer experience. This method measures customer acceptance at the end of the product life cycle. It is more suitable for the evaluation of products and services that have been implemented. It is, therefore, evident that the evaluation of products and services based on customer value has been recognised by an increasing number of scholars. However, there is still a lack of studies regarding the acceptance of ASP [45] and few efforts have been made to understand customer behaviour in the context of ASP [46].

Based on the aforementioned theory, we propose to evaluate customer acceptance of ASP by quantitatively measuring customer value. The measurement of customer value is reflected in two ways. On one hand, it can be reflected in the perceived difference between benefits and sacrifices [47] (i.e., benefits minus sacrifices). The relevant concepts are as follows: the price a customer is willing to pay for a product and the willingness to pay is the perceived benefit that the product provides to the customer [48]. Customer value is the difference between the total customer value and the total cost [49]. On the other hand, it can also be reflected by the ratio of the perceived benefits to sacrifices [50] (i.e., benefits divided by sacrifices). The relevant concepts are as follows: customer value is the ratio of perceived benefits to perceived costs [51]. Customer value is the perceived tradeoff between multiple gains and losses [52]. In the context of benefits and sacrifices, customer value is the perceived trade-off between the multiple benefits and sacrifices incurred by the customer [53]. From the perspective of sustainability, we use "benefits divided by sacrifices", because it is more sustainable to meet customer needs by using the minimum resources possible.

Furthermore, measurement of customer value not only includes utility, cost and customer need, but also personalised characteristics [54]. Personalisation is considered to be an approach for prolonging the value lifetime of a product and minimizing resource input [55]. Different customer groups have varying personalised features. Therefore, offering the same kind of ASP cannot satisfy the personalised needs of these customers [56,57]. Manufacturers must understand the effects of different quality attributes in order to allocate resources to increase customer satisfaction or minimise dissatisfaction [58]. They also hope that providing tailored ASP to specific customer segments can also assist in the conservation of resources and the improve customer value $[59,60]$, thereby building customer loyalty [55]. However, personalisation for individuals greatly increases the difficulty of customer management. In addition, when an individual customer requires a change during the product use phase, it is usually expected that service processes and resources be re-arranged. This could lead to an increase in service response time, while also causing previous designs to be wasted [61]. Therefore, "personalisation of customer segment" is appropriate for manufacturers in the initial stage 
of attempting ASP, because many manufacturers segment their customers. The personalised customer value in this report is a description of customer segment perception.

\section{Method}

Based on the preceding discussion, this study proposes a quantitative method for measuring the difference in customer value between products with or without ASP to evaluate customer acceptance of ASP. To quantitatively describe the personalisation of customer value, specific features, including utility and input for different customer segments, is proposed. In addition, we add a supply-demand coefficient to represent the different supply-demand relationship between different customer segments. The evaluation model of customer acceptance includes personalised customer value and the supply-demand coefficient. The customer acceptance has a positive correlation with these factors. The personalised customer value includes utility and input. There is a positive correlation between personalised customer value and utility, but a negative correlation between personalised customer value and input. The supply-demand coefficient includes utility and expectation. There is a positive correlation between supply-demand coefficient and utility, and a negative correlation between supply-demand coefficient and expectation. By comparing the customer value before and after the addition of service, the customer acceptance of ASP can be evaluated, as shown in Figure 1.

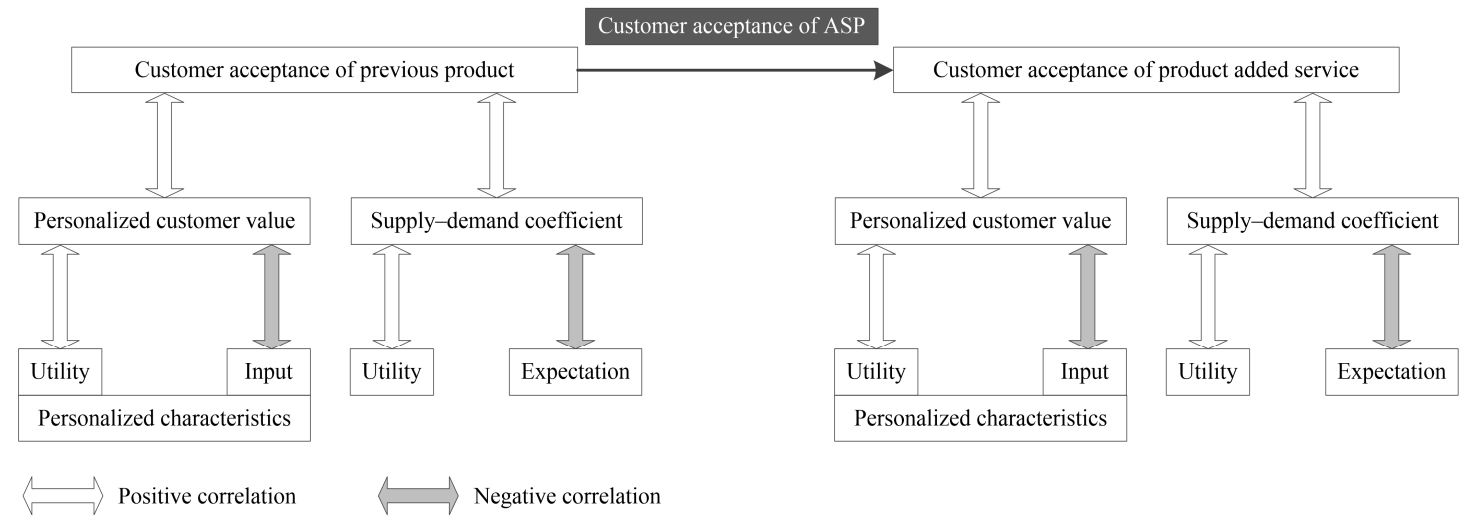

Figure 1. Customer acceptance evaluation method of ASP.

\subsection{Methods for Quantitatively Describing Personalised Customer Value}

The benefits perceived by customers include not only the functional aspects of the product, but also the social value, hedonic value, pragmatic value, etc. [62-64]. Utility has been described by Oliver as strictly a cognitive concept that relates to usefulness, hedonic quality, pleasure, and even satisfaction [65]. Many scholars have included this construct in the definition of customer value, referring to any benefit that contributes to an offer and allows the customer to achieve his or her goals [66-68]. Therefore, we use "Utility" to describe the various needs of the customer.

Definition 1. Utility: the ability to satisfy customer needs, including function, quality, pleasure, satisfaction, etc. (i.e., the perceived benefit to the customer).

The client will not always want a low price, but instead, good value for the money spent. In this case, non-monetary sacrifices related to service could also be more important to the consumer, such as time [62,63]. Customer value has a negative function on monetary (prices) and non-monetary sacrifices [69].

Definition 2. Input: the monetary, temporal, environmental and mental cost to the customer to obtain the product (i.e., the perceived sacrifice by the customer). 
Assume that the product is $\mathrm{P}$, the upgraded product with the inclusion of an ASP is $\mathrm{S}$, the product utility vector is $U$, the input vector is $C$, the customer needs vector is $D$, the individual feature vector is $\mathrm{F}$, the number of elements in the product utility vector is $\mathrm{m}$, and the number of elements in the input vector is $n, i=1,2,3, \ldots, m$, and $j=1,2,3, \ldots, n$.

Assume that the original product utility vector is $U_{P}=\left[u_{P i}\right]=\left(u_{P 1}, u_{P 2}, \ldots, u_{P i}, \ldots, u_{P m}\right)^{T}$;

The upgraded product utility vector is $U_{S}=\left[u_{S i}\right]=\left(u_{S 1}, u_{S 2}, \ldots, u_{S i}, \ldots, u_{S m}\right)^{T}$;

The original product input vector is $C_{P}=\left[c_{P j}\right]=\left(c_{P 1}, c_{P 2}, \ldots, c_{P j}, \ldots, c_{P n}\right)^{T}$;

The upgraded product input vector is $C_{S}=\left[c_{S j}\right]=\left(c_{S 1}, c_{S 2}, \ldots, c_{S j}, \ldots, c_{S n}\right)^{T}$; and

The product utility requirement vector for a specific customer group is $D=\left[d_{i}\right]=$ $\left(d_{1}, d_{2}, \ldots, d_{i}, \ldots, d_{m}\right)^{T}$;

The personalised customer value represents a multifarious perception of utility and input for different customer segments. In this study, the characteristics of personalised customer value comprise the characteristics of personalised utility and input. Among them, the former represents the personalised perception of the given customer segment regarding the weights assigned to each product utility factor, and the latter represents the personalised perception of the weights assigned to each input factor.

The vector of personalised utility characteristics is $F_{V}=\left[f_{V i}\right]=$ $\left(f_{V 1}, f_{V 2}, \ldots, f_{V i}, \ldots, f_{V m}\right)^{T}, \sum_{i=1}^{i=m} f_{V i}=1$.

The vector of personalised input characteristics is $F_{C}=\left[f_{C i}\right]=$ $\left(f_{C 1}, f_{C 2}, \ldots, f_{C j}, \ldots, f_{C n}\right)^{T}, \sum_{i=1}^{i=n} f_{c i}=1$.

Because the utility and input vectors contain multiple factors, the vector cross-product is used to perform the calculations in this study.

The perceived utility of the original product by the customer segment, $E_{U P}$, is given by:

$$
E_{U P}=\left|U_{P} \times F_{V}\right|=\left(u_{P 1}, u_{P 2}, \ldots, u_{P i}, \ldots, u_{P m}\right)^{T} \times\left(f_{V 1}, f_{V 2}, \ldots, f_{V i}, \ldots, f_{V m}\right)^{T}=\sum_{i=1}^{i=m} u_{P i} f_{V i}
$$

The perceived utility of the upgraded product by the customer segment, $E_{U S}$, is given by:

$$
E_{U S}=\left|U_{S} \times F_{V}\right|=\left(u_{S 1}, u_{S 2}, \ldots, u_{S i}, \ldots, u_{S m}\right)^{T} \times\left(f_{V 1}, f_{V 2}, \ldots, f_{V i}, \ldots, f_{V m}\right)^{T}=\sum_{i=1}^{i=m} u_{S i} f_{V i}
$$

The perceived input for the original product by the customer segment, $E_{C P}$, is given by:

$$
E_{C P}=\left|C_{P} \times F_{C}\right|=\left(c_{P 1}, c_{P 2}, \ldots, c_{P j}, \ldots, c_{P n}\right)^{T} \times\left(f_{C 1}, f_{C 2}, \ldots, f_{C j}, \ldots, f_{C n}\right)^{T}=\sum_{i=1}^{i=n} c_{P j} f_{C j}
$$

The perceived input for the upgraded product by the customer segment, $E_{C S}$, is given by:

$$
E_{C S}=\left|C_{S} \times F_{C}\right|=\left(c_{S 1}, c_{S 2}, \ldots, c_{S j}, \ldots, c_{S n}\right)^{T} \times\left(f_{C 1}, f_{C 2}, \ldots, f_{C j}, \ldots, f_{C n}\right)^{T}=\sum_{i=1}^{i=n} c_{S j} f_{C j}
$$

\subsection{Evaluation Model}

Personalisation of customer segments not only contains the different perception of utility and cost, but also the different supply-demand relationship between different customer segments. Therefore, we introduce the supply-demand coefficient to express the relationship between customer demand and utility provision: $\alpha_{P}=\sum_{i=1}^{i=m}\left[\frac{\min \left(u_{i}, d_{i}\right)}{\max \left(u_{i}, d_{i}\right)} \times f_{v i}\right]$.

Simple confirmation occurs when perceptions meet expectations, and a positive (negative) acceptance occurs when the perception of service delivery is above (below) expectations [70,71]. Exceeding the expectations of customers will leads to delight, and utility is positively correlated with customer value [72,73]. Therefore, we add " $l$ " and " $k$ " to distinguish between exceeding customer expectations and not. The supply-demand coefficient can be optimised as follows: $\alpha_{P}=\sum_{i=1}^{i=m}\left[\frac{\min \left(u_{i}, d_{i}\right)}{\max \left(u_{i}, d_{i}\right) \times l} \times(1+k) \times f_{v i}\right]$, when $d_{i}>u_{S i}, k=\frac{d_{i}-u_{S i}}{d_{i}}, l=0, d_{i}>u_{S i}$, when $d_{i} \leq u_{S i}, k=$ $0, l=1$. 
The supply-demand coefficient of the original product for a customer segment is $\alpha_{P}=$ $\sum_{i=1}^{i=m}\left[\frac{\min \left(u_{P_{i}}, d_{i}\right)}{\max \left(u_{P_{i}}, d_{i}\right) \times l} \times(1+k) \times f_{v i}\right]$, the personalised perceived value of the original product for a customer segment is $\frac{E_{U P}}{E_{C P}} \times \alpha_{P}$, the supply-demand coefficient of the upgraded product for a customer segment is $\alpha_{S}=\sum_{i=1}^{i=m}\left[\frac{\min \left(u_{S i}, d_{i}\right)}{\max \left(u_{S i}, d_{i}\right) \times l} \times(1+k) \times f_{v i}\right]$, and the personalised perceived value of the upgraded product for a customer segment is $\frac{E_{U S}}{E_{C S}} \times \alpha_{S}$. The ASP evaluation model based on personalised customer value can now be obtained by subtracting the customer value of the original product as seen by the customer segment from that of the upgraded product as follows:

$$
E_{P-S}=\frac{E_{U S}}{E_{C S}} \times \alpha_{S}-\frac{E_{U P}}{E_{C P}} \times \alpha_{P}
$$

Using this model, we can identify customer perception of ASP to determine acceptability of ASP. In an ideal situation, the inclusion of the optimal ASP improves product utility and yields a better match with customer needs without incurring significant extra input. Therefore, the evaluation yields a positive value, indicating that the ASP can improve customer value and should be considered in the final plan. The model developed here can be used to rank ASPs that target different customer groups to identify the optimal situation that maximises personalised customer value.

\section{Case Analysis}

A fire equipment manufacturer planned to upgrade its portable fire extinguishers by adding ASPs. Based on the available information, service personnel, and service equipment, two service items were proposed: (1) guided training, and (2) maintenance. The manufacturer had segmented the target customers into white-collars and drivers, and the promotion methods for each group were totally different. Products were promoted to white-collars online, while in the case of drivers, offline promotion was adopted. In addition, white-collars buy fire equipment mainly for indoor fire prevention, whereas drivers buy fire equipment for mainly to prevent car fires. So white-collars and drivers were taken into consideration as two customer segments, as shown in Figure 2. This manufacturer wanted to estimate which service item would be better accepted by customers in order to appropriately adjust their service resources.

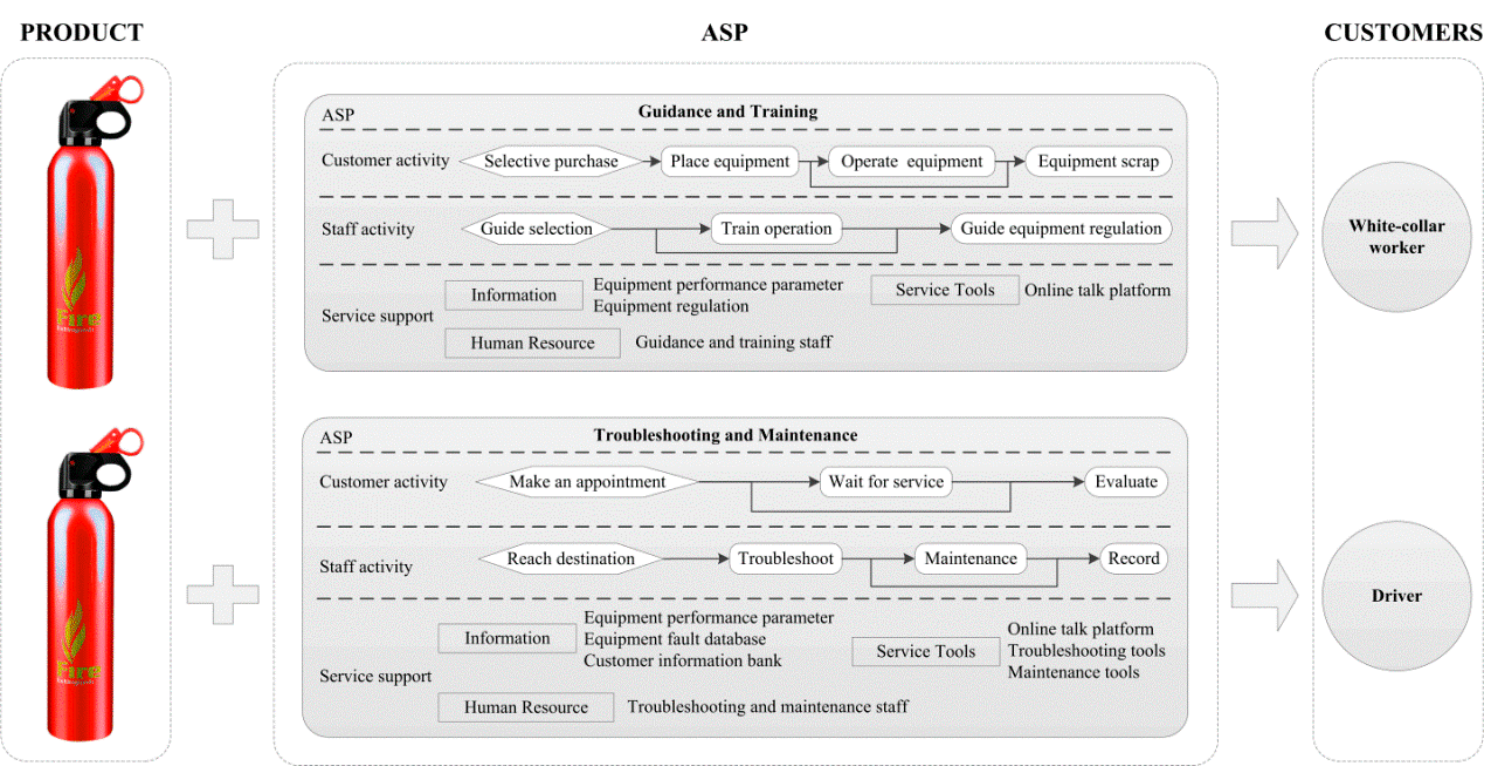

Figure 2. Product upgrades targeting different customer segments.

Moreover, other distractions should be eliminated before testing. Firstly, individuals tend to value a high sense of affiliation to others (e.g., family and reference group), so social interactions interpersonal 
engagement further influencing their decision making [74]. Secondly, environment has great influence on customer value [75]. Thirdly, emotions and cognition will impact the customer, such as experience with similar products and current mood [64]. Therefore, we need to reduce the impact of interference factors on customer value before and after adding ASPon the premise that the difference of customer segments should be kept. We invited one hundred bank staffs (as a representative of white-collar workers) with $50 \%$ respondents being males, and taxi drivers (as a representative of drivers) with $50 \%$ respondents being males. All respondents who aged from 26 to 31 had graduated from high school or above and they had worked over 5 years. The professional background of bank staffs is economical, and the professional background of taxi drivers is technical. They all experienced using portable fire extinguishers once. Then we went to the field where respondents received the promotional information (bank staffs received advertisements by APP in office; taxi drivers received advertisements by flyers) All survey was proceeding on a one-to-one basis in $11 \mathrm{am}$ to $1 \mathrm{pm}$. Make sure respondents were free and calm in the survey process Survey took place over a three week period in two eastern third-tier cities in the China.

\subsection{Data Collection}

The utility perceived by customers can be classified into functionality, convenience, temporal effectiveness, economics, environmental friendliness and emotional satisfaction, based on the statistical analysis of the relevant factor of utility in customer feedback. The utility of the portable fire extinguishers, $U_{P}$, can be described using the following dimensions:

Practicability $u_{P 1}$ : The fire extinguishing function of portable fire extinguishers is effective and reliable.

Convenience $u_{P 2}$ : The product is small and located in a convenient location for quick use.

Efficiency $u_{P 3}$ : The product has a short start uptime and high extinguishing efficiency.

Security $u_{P 4}$ : The product is safe during installation and storage.

Operability $u_{P 5}$ : The product is easy to operate with less misoperation.

Emotional satisfaction $u_{P 6}$ : The product provides greater confidence and better emotional security in controlling a fire.

According to the definition of input used in this section, the input of the portable fire extinguishers, $C_{P}$, can be described using the following dimensions:

Monetary $\operatorname{cost} c_{P 1}$ : Customers spend less on purchase, maintenance and recycling.

Temporal $\operatorname{cost} c_{P 2}$ : The time consumption in the process of purchase, study and use.

Environmental cost $c_{P 3}$ : Material and energy consumption; environmental pollution after use or misuse.

Mental cost $c_{P 4}$ : The vigour and spiritual consumption of customers entailed by understanding, accepting, study and use.

We used a Likert-type rating scale, which is one of the most used tools for data collection in the design of questionnaire [76]. All factors of the vectors were set up into 5 scales. For example, the practicability of the portable fire extinguishers has 5 factors: Effectiveness-can extinguish a variety of fires; Reliability - low failure rate; Heat resistance — can be used in a high-temperature environment; Sturdiness-not easily damaged; Useful life-long service life. The five factors of practicability were evaluated using 5-step scales, including "strongly agree, agree, indifferent, disagree, strongly disagree". Finally, all factors were converted to decimal format.

In this way, a survey consisting of 32 items was developed. Prior to undertaking the main survey, a pretest was performed to assess the validity of the scale items. 78 respondents were invited to fill out the questionnaire online via social software. We initially assessed the reliability, composite reliability and discriminant validity of the measures and determined that all constructs had an acceptable level $(\lambda \geq 0.7, \alpha \geq 0.7, \operatorname{AVE} \geq 0.5, \mathrm{CR} \geq 0.6)[77,78]$, as shown in Tables A1 and A2. From this 
analysis, it was determined that no items would be eliminated or modified based on the pretest to the main study.

The main survey was performed, and the utility and input vectors of the two upgraded products were estimated and scored accordingly. For example, the functionality of the portable fire extinguishers was assigned a score of eight and the guided training service was estimated to increase the functionality of $\mathrm{S} 1$ by $25 \%$. Specifically, the functionality of S1 was estimated to be 10 . Following a similar process, raw data for the utility and general input vectors of the original product and the two upgraded products can then be obtained as follows:

The utility vector of the portable fire extinguishers is $U_{P}=(8,6,4,6,3,5)$.

The utility vector of the portable fire extinguishers with a guided training service is $U_{S 1}=$ $(10,8,6,5,4,6)$.

The utility vector of the portable fire extinguishers with maintenance service is $U_{S 2}=$ $(8,6,4,8,6,8)$.

The general input vector of the portable fire extinguishers is $C_{P}=(4,4,3,3)$.

The general input vector of the portable fire extinguishers with a guided training service is $C_{S 1}=(5,5,2,2)$.

The general input vector of the portable fire extinguishers with maintenance service is $C_{S 2}=$ $(3,5,1,3)$.

The test results were compiled to perform quantitative statistical analysis and to obtain raw data on the utility requirements and personalised features of the two customer groups for the portable fire extinguishers.

The raw data obtained based on the statistical analysis of the white-collar and driver groups were as follows.

The utility requirement vector of the portable fire extinguishers for the white-collar group is $D_{(W)}=(8.3,6.3,4.5,8.4,6,9.2)$.

The utility requirement vector of the portable fire extinguishers for the driver group is $D_{(D)}=$ $(9.2,8.8,5.1,5.7,6.5,7)$.

The importance of personalised value characteristics to the white-collar and driver groups is evaluated using a five-level quantitative evaluation system. The results are further used to calculate the weight of each factor for the customer utility and input vectors, as shown in Table 1.

Table 1. Results of personalised feature analysis.

\begin{tabular}{|c|c|c|c|c|c|c|}
\hline \multicolumn{7}{|c|}{ The Results of Personalised Feature Analysis for the White-Collar Group } \\
\hline \multirow[b]{2}{*}{ Items } & \multicolumn{5}{|c|}{ Importance of Evaluation } & \multirow[b]{2}{*}{ Weights } \\
\hline & $\begin{array}{c}\text { Not Important } \\
(0.07)\end{array}$ & $\begin{array}{c}\text { Somewhat Important } \\
(0.13)\end{array}$ & $\begin{array}{l}\text { Important } \\
(0.2)\end{array}$ & $\begin{array}{c}\text { Very Important } \\
(0.27)\end{array}$ & $\begin{array}{c}\text { Extremely Important } \\
(0.33)\end{array}$ & \\
\hline Practicability & 0 & 0 & 2 & 7 & 91 & 0.35 \\
\hline Convenience & 63 & 34 & 2 & 1 & 0 & 0.1 \\
\hline Efficiency & 57 & 43 & 0 & 0 & 0 & 0.1 \\
\hline $\begin{array}{l}\text { Emotional } \\
\text { satisfaction }\end{array}$ & 4 & 35 & 36 & 18 & 7 & 0.21 \\
\hline Monetary cost & 8 & 32 & 51 & 9 & 0 & 0.21 \\
\hline Time cost & 45 & 43 & 11 & 1 & 0 & 0.14 \\
\hline $\begin{array}{l}\text { Environmental } \\
\text { cost }\end{array}$ & 1 & 0 & 12 & 29 & 58 & 0.35 \\
\hline
\end{tabular}


Table 1. Cont.

\begin{tabular}{|c|c|c|c|c|c|c|}
\hline \multicolumn{7}{|c|}{ The Results of Personalised Feature Analysis for the Driver Group } \\
\hline \multirow{2}{*}{$\begin{array}{l}\text { Evaluation } \\
\text { Items }\end{array}$} & \multicolumn{5}{|c|}{ Importance of Evaluation } & \multirow[b]{2}{*}{ Weights } \\
\hline & $\begin{array}{c}\text { Not Important } \\
(0.07)\end{array}$ & $\begin{array}{c}\text { Somewhat Important } \\
(0.13)\end{array}$ & $\begin{array}{l}\text { Important } \\
(0.2)\end{array}$ & $\begin{array}{c}\text { Very Important } \\
(0.27)\end{array}$ & $\begin{array}{c}\text { Extremely Important } \\
(\mathbf{0 . 3 3 )}\end{array}$ & \\
\hline Practicability & 0 & 0 & 1 & 17 & 82 & 0.31 \\
\hline Convenience & 7 & 26 & 17 & 39 & 11 & 0.21 \\
\hline Efficiency & 25 & 24 & 33 & 18 & 0 & 0.16 \\
\hline $\begin{array}{l}\text { Emotional } \\
\text { satisfaction }\end{array}$ & 15 & 39 & 43 & 3 & 0 & 0.15 \\
\hline Monetary cost & 39 & 47 & 12 & 1 & 1 & 0.15 \\
\hline Time cost & 8 & 32 & 45 & 15 & 0 & 0.23 \\
\hline $\begin{array}{l}\text { Environmental } \\
\text { cost }\end{array}$ & 0 & 2 & 1 & 9 & 88 & 0.41 \\
\hline
\end{tabular}

Based on the data shown in Table 1, the following results can be obtained. The feature vector of the utility needs of the portable fire extinguishers for the white-collar group is $F_{V(W)}=$ $(0.35,0.1,0.1,0.08,0.16,0.21)$, while of the utility requirement of the portable fire extinguishers for the driver group is $F_{V(D)}=(0.31,0.21,0.16,0.09,0.08,0.15)$, the feature vector of the input of the portable fire extinguishers for the white-collar group is $F_{C(W)}=(0.21,0.14,0.35,0.3)$, and that of the portable fire extinguishers for the driver group is $F_{C(D)}=(0.15,0.23,0.41,0.21)$.

\subsection{Data Analysis and Results}

Substituting the raw data into Equations (1)-(4) yields the perceived utility, perceived input, and supply-demand coefficient evaluation of the original product, upgraded product S1, and upgraded product $\mathrm{S} 2$ for the white-collar and driver groups. By substituting these results into Equation (5), we can assess changes to customer value of customers for the white-collar and driver groups when guided training service and maintenance service are provided, as shown in Table 2.

Table 2. Evaluation of ASPs for portable fire extinguishers based on personalised customer needs.

\begin{tabular}{|c|c|c|c|}
\hline Customer Evaluation & Original Product & Upgraded Product S1 & Upgraded Product S2 \\
\hline Perceived utility (white collar) & $E_{U P(W)}=5.81$ & $E_{U S 1(W)}=7.2$ & $E_{U S 2(W)}=7.08$ \\
\hline Perceived utility (driver) & $E_{U P(D)}=5.91$ & $E_{U S 1(D)}=7.41$ & $E_{U S 2(D)}=6.78$ \\
\hline Perceived input (white collar) & $E_{C P(W)}=3.35$ & $E_{C S 1(W)}=3.05$ & $E_{C S 2(W)}=2.58$ \\
\hline Perceived input (driver) & $E_{C P(D)}=3.38$ & $E_{C S 1(D)}=3.14$ & $E_{C S 2(D)}=2.64$ \\
\hline Supply-demand coefficient (white collar) & $\alpha_{P(W)}=0.77$ & $\alpha_{P S 1(W)}=0.92$ & $\alpha_{P S 2(W)}=0.94$ \\
\hline Supply-demand coefficient (driver) & $\alpha_{P(D)}=0.72$ & $\alpha_{P S 1(D)}=0.95$ & $\alpha_{P S 2(D)}=0.83$ \\
\hline ASP evaluation (white collar) & $+(D)$ & $E_{P-S 1(W)}=0.84$ & $E_{P-S 2(W)}=1.5$ \\
\hline ASP evaluation (driver) & & $E_{P-S 1(D)}=0.98$ & $E_{P-S 2(D)}=0.87$ \\
\hline
\end{tabular}

The results reveal positive evaluations for all four ASPs, indicating that both guided training and maintenance service can improve customer value for the white-collar and driver groups. In particular, the maintenance service targeting white-collar groups has the highest score. This result shows that providing maintenance service to the white-collar group has the most significant impact on improving customer value. Therefore, manufacturers should give priority to implementing maintenance service.

Finally, the manufacturer performed a small-scale implementation of ASP to verify the effectiveness of the aforementioned method. Two service items-guided training service and maintenance service-were generalised in two third-tier cities, respectively. After three months, both offline and online sales were counted and compared with the sales of portable fire extinguishers over three months, as shown in Table 3. After implementing guided training in city A, we calculated that the sales growth rate of drivers was greater than that of white-collars. This demonstrates that the guided training service is better accepted by drivers. The results of city B demonstrate that maintenance 
service is better accepted by white-collars. These test results are in good agreement with the results for customer acceptance in Table 2.

Table 3. Test results for small-scale market acceptance.

\begin{tabular}{llllll}
\hline & ASP & Sales Volume & White-Collars & Drivers & Others \\
\hline \multirow{2}{*}{ City A } & NO & 1687 & 673 & 758 & 247 \\
\multirow{2}{*}{ Sales growth } & Guided training & 2047 & 791 & 969 & 287 \\
\cline { 4 - 6 } City B & \multirow{2}{*}{ SO } & $24.9 \%$ & $17.5 \%$ & $27.8 \%$ & $16.2 \%$ \\
Sales growth & Maintenance & 1820 & 719 & 824 & 277 \\
\cline { 3 - 6 } & & 2355 & 1033 & 1004 & 318 \\
\end{tabular}

\section{Discussion}

Manufacturers take sustainability into consideration with an emphasis on resources. ASP is a recommended approach for supporting sustainability. In this report, the relationship between ASP and sustainable innovation is discussed. Based on a review of the literature, we determined that there is a significant relationship between the two. Service is inherently intangible. Expanding product functions to meet customer needs via service and the reduction of the use of tangible materials are sustainable innovations [15-17]. However, the service will consume fuel, energy and other resources, and unacceptable service will waste resources [18-21], which is unsustainable.

It is desirable that manufacturers provide the most accepted ASP to different customer segments before implementation. However, the limitations of common service evaluation methods do not support the measurement of customer acceptance. One difficulty is that the decision by customers to accept ASP occurs before it is experienced. The other is that the ASP is not isolated from the product. Customers evaluate the product with ASP as an integrated product. The common service evaluation method cannot be used to evaluate ASP.

Fortunately, we determine that customer value may be a measurement criterion by which the perceptions of the customer can be represented. We then proposed the main point of this paper-that customer value can be measured to evaluate customer acceptance of ASP — and prove this assertion based on two aspects. On one hand, we considered the relationship between customer value and customer acceptance [39-42]. The first point, that customer value comes prior to and is conclusive for customer acceptance, was then advanced. On the other hand, we discussed the application of customer value in product and service evaluation $[43,44]$. Then we proposed the second point, that customer value can be measured to evaluate ASP. In addition, we confirmed that "benefits divided by sacrifices" is more appropriate for customer value considering sustainability. Based on these conclusions, a model was proposed to evaluate customer acceptance. In this model, the difference in customer value between a product with and without ASP can be measured. We use "utility", which is the ability to satisfy customer needs as a representative of the perceived benefit to the customer; and "input", which includes monetary, temporal, environmental and mental cost, taken as being representative of perceived sacrifice by the customer. Considering the different needs of different customer segments, the vectors of personalised characteristics and the supply-demand coefficient are proposed to quantitatively describe personalisation of customer segments.

Finally, we established the feasibility of the proposed method by quantitatively measuring the difference between the customer value of white-collars and drivers in order to evaluate customer acceptance. According to the evaluation results of customer acceptance, suggestions for the implementation of ASP were presented. Furthermore, we added the results of a small-scale market test that are consistent with the results and recommendations of the customer acceptance evaluation to prove the effectiveness of the proposed method. 


\section{Conclusions}

The service object of this paper focuses on manufacturers who try to integrate services into products. Customer acceptance of ASP is the first step towards sustainability. An evaluation method for customer acceptance is required because manufactures ideally want to offer the most accepted ASP to customers prior to implementation to avoid wasting resources. Customer acceptance cannot be determined via evaluating services because customers make a decision regarding acceptance before the ASP is experienced. Moreover, from the customer's perspective, they evaluate the product associated with the ASP as an integrated product, rather than just a service. This report proposes to evaluate customer acceptance based on customer value. This paper proposes to evaluate customer acceptance based on customer value.

\subsection{Managerial Implications}

Initially, we discussed the relationship between customer value and customer acceptance. We proposed the first point that customer value comes prior to and is conclusive for customer acceptance. Secondly, we discussed the application of customer value in product and service evaluation. Then we proposed the second point that customer value can be measured to evaluate ASP. In addition, the common service method is not applicable to the evaluation of customer acceptance of ASP. Considering these bases, we proposed the main point of this paper: that customer value can be measured to evaluate customer acceptance of ASP which can be considered as part of the service solution evaluation. This assertion fosters new thinking and application of an evaluation method based on customer value. On the basis of the above theory, we advanced a specific measurement method for customer acceptance. The difference between customer value of products with and without ASP was quantitatively measured to evaluate customer acceptance of ASP. Moreover, we used the personalised features and the supply-demand coefficient to describe the personalisation of different customer segments. In this way, manufacturers can provide the most acceptable ASP for different customer segments and adjust service resources by predicting customer acceptance for different ASPs to satisfy customer expectation using minimal resource.

\subsection{Limitations and Future Research}

As in any study, there are limitations to this study and its findings that should be addressed. Firstly, incorporating ASP in products is a complex and systematic procedure, which often involves the addition of multiple ASPs to the product at the same time. The type and sequence of different ASPs included in products affects the value perceived by the customer. Secondly, there are many other factors that influence customer acceptance in addition to the properties of the ASP, such as marketing approach and social interaction. The feasibility and effectiveness of the method proposed in this paper were evaluated in an ASP project at the initial stage of innovation. The conclusions of this study can be considered as a basis for establishing a comprehensive evaluation system to measure the customer value of complicated systems that contain products and services.

Author Contributions: Data curation, D.F. Funding acquisition, S.J. Investigation, D.F. Methodology, S.J. Project administration, C.L. Resources, C.L. Supervision, S.J. Validation, S.J. Writing-original draft, D.F.; Writing一review and editing, D.F.

Funding: This project was supported by the National Natural Science Foundation of China (No. U1610112).

Acknowledgments: We thank the Industrial Design and Technology Innovation Platform of Zhejiang Province for support in data collection for PSS design projects.

Conflicts of Interest: The authors have no conflict of interest to declare. 


\section{Appendix A}

Table A1. Reliability analysis of survey items.

\begin{tabular}{|c|c|c|c|c|}
\hline Items & Subdivision & Description & $\begin{array}{c}\text { Item Reliability } \\
(\lambda \geq 0.7)\end{array}$ & $\begin{array}{l}\text { Measuring Error } \\
\quad(\theta<0.5)\end{array}$ \\
\hline \multirow{5}{*}{ Q1: Practicability } & Effectiveness & Can extinguish a variety of fires & 0.893 & 0.203 \\
\hline & Reliability & Low failure rate & 0.831 & 0.309 \\
\hline & Heat resistance & Can be used in a high temperature environment & 0.824 & 0.321 \\
\hline & Sturdiness & Not easily damaged & 0.832 & 0.308 \\
\hline & Useful life & Long service life & 0.810 & 0.344 \\
\hline \multirow{3}{*}{ Q2: Convenience } & Small in size & Small volume and easy to store & 0.864 & 0.254 \\
\hline & Installation site & Suitable for a variety of installation sites and easy to install & 0.803 & 0.355 \\
\hline & Fast delivery & Quick delivery, immediate protection & 0.846 & 0.284 \\
\hline \multirow{4}{*}{ Q3: Efficiency } & Quick start & Short start-up time, less waiting & 0.809 & 0.346 \\
\hline & Rapid fire extinguishing & Put out the fire quickly and reduce the loss & 0.894 & 0.201 \\
\hline & Prevent reburning & Completely extinguishing the fire to reduce the potential reburning hazard & 0.856 & 0.267 \\
\hline & Conspicuous & Very visible and easy to find & 0.835 & 0.303 \\
\hline \multirow{3}{*}{ Q4: Security } & Safety in use & Ensure the safety of the use process & 0.921 & 0.152 \\
\hline & Safety in installing & Ensure the safety of installation process & 0.878 & 0.229 \\
\hline & Safety in storage & Ensure the safety of storage process & 0.787 & 0.381 \\
\hline \multirow{2}{*}{ Q5: Operability } & Reasonable process & The operation process is in line with user habits & 0.864 & 0.254 \\
\hline & Less misoperation & Clear steps, reduce the possibility of misoperation & 0.791 & 0.374 \\
\hline \multirow{3}{*}{ Q6: Emotional satisfaction } & Sense of security & Make the user feels at ease, feel the life has safeguard & 0.891 & 0.206 \\
\hline & Responsibility & The sense of responsibility and fire awareness of users & 0.806 & 0.350 \\
\hline & Regulation & Relevant regulations require firefighting facilities & 0.844 & 0.288 \\
\hline \multirow{4}{*}{ Q7: Monetary cost } & Purchasing costs & Low production cost, high cost performance & 0.902 & 0.186 \\
\hline & Delivery costs & Fast delivery speed and low logistics cost & 0.799 & 0.362 \\
\hline & Maintenance costs & Easy maintenance and low maintenance cost & 0.806 & 0.350 \\
\hline & Retirement costs & Low scrap rate, reduce resource waste & 0.789 & 0.377 \\
\hline \multirow{4}{*}{ Q8: Time cost } & Learning time & Easy to learn operation & 0.813 & 0.339 \\
\hline & Operating time & Less operation steps, fast fire extinguishing speed & 0.892 & 0.204 \\
\hline & Set-up time & Less installation steps and less installation time & 0.814 & 0.337 \\
\hline & Maintenance time & Low probability of damage and simple maintenance & 0.825 & 0.319 \\
\hline \multirow{2}{*}{ Q9: Environmental cost } & Environmental harm & Environmentally friendly, in line with environmental protection & 0.851 & 0.276 \\
\hline & Materials consumption & The raw material is pollution-free and in line with sustainable development & 0.793 & 0.371 \\
\hline \multirow{2}{*}{ Q10: Mental cost } & Vigour costs & The operation is easy and effortless & 0.789 & 0.377 \\
\hline & Spiritual costs & Less steps, simple operation process, users are free of a burden & 0.814 & 0.337 \\
\hline
\end{tabular}




\section{Appendix B}

Table A2. Composite reliability and discriminant validity analysis of survey items.

\begin{tabular}{|c|c|c|c|c|c|c|c|c|c|c|c|c|c|}
\hline $\begin{array}{l}\text { Cronbach 's Alpha } \\
(\alpha \geq 0.7)\end{array}$ & $\begin{array}{c}\text { AVE } \\
(\mathrm{AVE} \geq 0.5)\end{array}$ & Composite Reliability (CR $\geq 0.6$ ) & Items & Q1 & Q2 & Q3 & Q4 & Q5 & Q6 & Q7 & Q8 & Q9 & Q10 \\
\hline 0.941 & 0.703 & 0.922 & Q1 & 0.838 & & & & & & & & & \\
\hline 0.943 & 0.702 & 0.876 & Q2 & 0.617 & 0.838 & & & & & & & & \\
\hline 0.934 & 0.721 & 0.912 & Q3 & 0.572 & 0.491 & 0.849 & & & & & & & \\
\hline 0.915 & 0.746 & 0.898 & Q4 & 0.329 & 0.327 & 0.331 & 0.864 & & & & & & \\
\hline 0.919 & 0.686 & 0.813 & Q5 & 0.437 & 0.523 & 0.554 & 0.41 & 0.828 & & & & & \\
\hline 0.889 & 0.719 & 0.884 & Q6 & 0.594 & 0.581 & 0.533 & 0.579 & 0.594 & 0.848 & & & & \\
\hline 0.947 & 0.681 & 0.895 & Q7 & 0.310 & 0.323 & 0.426 & 0.371 & 0.347 & 0.574 & 0.825 & & & \\
\hline 0.925 & 0.7 & 0.902 & Q8 & 0.514 & 0.547 & 0.622 & 0.391 & 0.589 & 0.541 & 0.302 & 0.837 & & \\
\hline 0.898 & 0.677 & 0.807 & Q9 & 0.326 & 0.394 & 0.341 & 0.51 & 0.379 & 0.483 & 0.332 & 0.355 & 0.823 & \\
\hline 0.874 & 0.643 & 0.782 & Q10 & 0.538 & 0.589 & 0.611 & 0.441 & 0.565 & 0.591 & 0.359 & 0.512 & 0.422 & 0.802 \\
\hline
\end{tabular}




\section{References}

1. Garrette, C.; Justin, K.; Long, N.H.; Marcel, C. Design for Sustainability: Current Trends in Sustainable Product Design and Development. Sustainability 2009, 1, 409-424. [CrossRef]

2. Porter, M.E.; Kramer, M.R. The big idea: Creating shared value. CFA Dig. 2011, 41, 12-13. [CrossRef]

3. Saviano, M.; Barile, S.; Clinton, S.J.; Caputo, F. A service research contribution to the global challenge of sustainability. J. Serv. Theory Pract. 2017, 27, 951-976. [CrossRef]

4. Vaux Halliday, S.; Trott, P. Relational, interactive service innovation: Building branding competence. Mark. Theory 2010, 10, 144-160. [CrossRef]

5. Annarelli, A.; Battistella, C.; Nonino, F. Product service system: A conceptual framework from a systematic review. J. Clean. Prod. 2016, 139, 1011-1032. [CrossRef]

6. Ahn, J.; Park, J. Product-to-Service Extension: The Impact of Brand Equity on Upscaled Service; John Wiley and Sons Ltd.: Hoboken, NJ, USA, 2016. [CrossRef]

7. Cherry, C.; Pidgeon, N. Why Is Ownership an Issue? Exploring Factors That Determine Public Acceptance of Product-Service Systems. Sustainability 2018, 10, 2289. [CrossRef]

8. Chen, K.H.; Wang, C.H.; Huang, S.Z.; Shen, G.C. Service innovation and new product performance: The influence of market-linking capabilities and market turbulence. Int. J. Prod. Econ. 2016, 172, 54-64. [CrossRef]

9. Tseng, M.-L.; Wu, K.-J.; Chiu, A.S.F.; Limd, M.K.; Tan, K. Service innovation in sustainable product service systems: Improving performance under linguistic preferences. Int. J. Prod. Econ. 2018, 203, 414-425. [CrossRef]

10. Shih, L.H.; Lee, Y.-T.; Huarng, F. Creating customer value for product service systems by incorporating internet of things technology. Sustainability 2016, 8, 1217. [CrossRef]

11. Baines, T.S.; Lightfoot, H.W.; Evans, S.; Neely, A.; Greenough, R.; Peppard, J.; Roy, R.; Shehab, E.; Braganza, A.; Tiwari, A.; et al. State of-the-art in product-service systems. Proc. Inst. Mech. Eng. Part B 2007, 221, 1543-1552. [CrossRef]

12. Fuchs, J.C.A.C.; Wagenknecht, C. Modular design of technical product-service systems. In Innovation in Life Cycle Engineering and Sustainable Development; Springer: Dordrecht, The Netherlands, 2006. [CrossRef]

13. Sakao, T.; Shimomura, Y. Service Engineering: A novel engineering discipline for producers to increase value combining service and product. J. Clean. Prod. 2007, 15, 590-604. [CrossRef]

14. Shimomura, Y.; Hara, T.; Arai, T. A unified representation scheme for effective PSS development. CIRP Ann. Manuf. Technol. 2009, 58, 379-382. [CrossRef]

15. Armstrong, C.M.; Lang, C. Sustainable product service systems: The new frontier in apparel retailing. Res. J. Text. Appar. 2013, 17, 1-12. [CrossRef]

16. Liedtke, C.; Buhl, J.; Ameli, N. Microfoundations for Sustainable Growth with Eco-Intelligent Product Service-Arrangements. Sustainability 2013, 5, 1141-1160. [CrossRef]

17. Pardo, R.J.H.; Bhamra, T.; Bhamra, R. Sustainable Product Service Systems in Small and Medium Enterprises (SMEs): Opportunities in the Leather Manufacturing Industry. Sustainability 2012, 4, 175-192. [CrossRef]

18. Mert, G.; Linke, B.S.; Aurich, J.C. Analysing the Cumulative Energy Demand of Product-service Systems for wind Turbines. Procedia CIRP 2017, 59, 214-219. [CrossRef]

19. Tukker, A.; Tischner, U. Product-services as a research field: Past, present and future. Reflections from a decade of research. J. Clean. Prod. 2006, 14, 1552-1556. [CrossRef]

20. Barquet, A.P.; Seidel, J.; Seliger, G.; Kohl, H. Sustainability factors for PSS business models. Procedia CIRP 2016, 47, 436-441. [CrossRef]

21. Beuren, F.H.; Gomes Ferreira, M.G.; Cauchick Miguel, P.A. Product-service systems: A literature review on integrated products and services. J. Clean. Prod. 2013, 47, 222-231. [CrossRef]

22. Raharjo, H. Dealing with Kano Model Dynamics: Strengthening the Quality Function Deployment as a Design for Six Sigma Tool. J. Tek. Ind. 2007, 9. [CrossRef]

23. Mont, O.K. Clarifying the concept of product-service system. J. Clean. Prod. 2002, 10, 237-245. [CrossRef]

24. Sampson, S.E. Visualizing service operations. J. Serv. Res. 2012, 15, 182-198. [CrossRef]

25. Hüer, L.; Hagen, S.; Thomas, O.; Pfisterer, H. Impacts of Product-Service Systems on Sustainability-A structured Literature Review. Procedia CIRP 2018, 73, 228-234. [CrossRef] 
26. Vargo, S.L.; Lusch, R.F. From goods to service(s): Divergences and convergences of logics. Ind. Mark. Manag. 2008, 37, 254-259. [CrossRef]

27. Lepak, D.P.; Smith, K.G.; Taylor, M.S. Value creation and value capture: A multilevel perspective. Acad. Manag. Rev. 2007, 32, 180-194. [CrossRef]

28. Timo, R.; Kaisa, K. From perceptions to propositions: Profiling customer value across retail contexts. J. Retail. Consum. Serv. 2017, 37, 159-167. [CrossRef]

29. Chen, Z.; Dubinsky, A.J. A conceptual model of perceived customer value in e-commerce: A preliminary investigation. Psychol. Mark. 2003, 20, 324-347. [CrossRef]

30. Vasantha, G.V.A.; Roy, R.; Lelah, A.; Brissaud, D. A review of product-service systems design methodologies. J. Eng. Des. 2012, 23, 25. [CrossRef]

31. Herbig, P.A.; Day, R.L. Customer acceptance: The key to successful introductions of innovations. Mark. Intell. Plan. 1992, 10, 4-15. [CrossRef]

32. Parasuraman, A.; Zeithaml, V.A.; Berry, L.L. SERVQUAL: A Multiple-Item Scale for Measuring Consumer Perceptions of Service Quality. J. Retail. 1988, 64, 12-40. [CrossRef]

33. Parasuraman, A.; Zeithaml, V.A.; Berry, L.L. A Conceptual Model of Service Quality and Its Implications for Future Research. J. Mark. 1985, 49, 41-50. [CrossRef]

34. Ade, O.; Peter, S. An examination of the role of service quality and perceived value in visitor attraction experience. J. Destin. Mark. Manag. 2009, 11, 1-9. [CrossRef]

35. Brady, M.; Cronin, J.J.; Cronin, M.K.B.J. Some New Thoughts on Conceptualizing Perceived Service Quality: A Hierarchical Approach. J. Mark. 2001, 65, 34-49. [CrossRef]

36. Cai, Z.; Yang, C. Research on the Extension Evaluation Model and Strategy Generation Method of Enterprise Service Quality. Procedia Comput. Sci. 2018, 139, 381-391. [CrossRef]

37. Gefen, D.; Karahanna, E.; Straub, D.W. Inexperience and experience with online stores: The importance of TAM and trust. IEEE Trans. Eng. Manag. 2003, 50, 307-321. [CrossRef]

38. Lee, S.; Geum, Y.; Lee, S.; Park, Y. Evaluating new concepts of PSS based on the customer value: Application of ANP and niche theory. Expert Syst. Appl. 2015, 42, 4556-4566. [CrossRef]

39. Chang, C.; Dibb, S. Reviewing and conceptualising customer-perceived value. Mark. Rev. 2012, 12, $253-274$. [CrossRef]

40. Woodruff, R.B. Customer Value: The Next Source for Competitive Advantage. J. Acad. Mark. Sci. 1997, 25, 139. [CrossRef]

41. Kashyap, R.; Bojanic, D.C. A Structural Analysis of Value, Quality, and Price Perceptions of Business and Leisure Travelers. J. Travel Res. 2000, 39, 45-51. [CrossRef]

42. Laurette, D.; Renaghan, L.M. Creating Visible Customer Value How Customers View Best-practice Champions. Cornell Hosp. Q. 2000, 41, 62-72. [CrossRef]

43. Chan, S.L.; Ip, W.H.; Cho, V. A model for predicting customer value from perspectives of product attractiveness and marketing strategy. Expert Syst. Appl. 2010, 37, 1207-1215. [CrossRef]

44. Xing, K.; Wang, H.F.; Qian, W. A sustainability-oriented multi-dimensional value assessment model for product-service development. Int. J. Prod. Res. 2013, 51, 5908-5933. [CrossRef]

45. Rexfelt, O.; HiortafOrnäs, V. Consumer acceptance of product-service systems Designing for relative advantages and uncertainty reductions. J. Manuf. Technol. Manag. 2009, 20, 674-699. [CrossRef]

46. Schenkl, S.A.; RöSch, C.; Mörtl, M. Literature Study on Factors Influencing the Market Acceptance of PSS. Procedia CIRP 2014, 16, 98-103. [CrossRef]

47. Anderson, J.C.; Narus, J.A. Business marketing: Understand what customers value. Harv. Bus. Rev. 1998, 76, 53-55. [CrossRef]

48. Christopher, M. Value-in-use Pricing. Eur. J. Mark. 1993, 16, 35-46. [CrossRef]

49. Kotler, P.; Keller, K.L.; Machek, M. Marketing management. Vision 2014, 17, 99.

50. Ravald, A.; Grönroos, C. The value concept and relationship marketing. Eur. J. Mark. 1996, 30, 19-30. [CrossRef]

51. Hoseason, J. Pricing: Making Profitable Decisions. J. Revenue Pricing Manag. 2003, 2, 175-177. [CrossRef]

52. Walter, A.; Ritter, T.; Gemünden, H.G. Value Creation in Buyer-Seller Relationships: Theoretical Considerations and Empirical Results from a Supplier's Perspective. Ind. Mark. Manag. 2001, 365-377. [CrossRef]

53. Forbis, J.L.; Mehta, N.T. Value-Based Strategies for Industrial Products. Bus. Horiz. 2006, 24, 32-42. [CrossRef] 
54. Desarbo, S.W.S. An Integrated Approach toward the Spatial Modeling of Perceived Customer Value. J. Mark. Res. 1998, 35, 236-249. [CrossRef]

55. Kaneko, K.; Kishita, Y.; Umeda, Y. In pursuit of personalization design. Procedia CIRP 2017, 61, 93-97. [CrossRef]

56. Chu, C.H.; Wang, I.J.; Wang, J.B.; Luh, Y.P. 3d parametric human face modeling for personalized product design. Adv. Eng. Inform. 2017, 32, 202-223. [CrossRef]

57. Lin, S.P.; Yang, C.L.; Chan, Y.H.; Sheu, C. Refining Kano's 'quality attributes-satisfaction' model: A moderated regression approach. Int. J. Prod. Econ. 2010, 126, 255-263. [CrossRef]

58. Fynes, B.; de Búrca, S. The effects of design quality on quality performance. Int. J. Prod. Econ. 2005, 96, 1-14. [CrossRef]

59. Tseng, M.M.; Jiao, R.J.; Wang, C. Design for mass personalization. CIRP Ann. Manuf. Technol. 2010, 59, 175-178. [CrossRef]

60. Valencia Cardona, A.M.; Mugge, R.; Schoormans, J.P.L.; Schifferstein, H.N.J. Challenges in the Design of Smart Product-Service Systems (SPSS): Experiences from Practitioners. In Design Management in an Era of Disruption; London, UK, 2014; ISBN 978-0-615-99152-8.

61. Song, W.; Sakao, T. A customization-oriented framework for design of sustainable product/service system. J. Clean. Prod. 2017, 140, 1672-1685. [CrossRef]

62. Berry, L.L.; Seiders, K.; Grewal, D. Understanding Service Convenience. J. Mark. 2002, 66, 1-17. [CrossRef]

63. Ruiz, D.M.; Gremler, D.D.; Washburn, J.H.; Carrión, G.C. Service value revisited: Specifying a higher-order, formative measure. J. Bus. Res. 2008, 61, 1278-1291. [CrossRef]

64. Berry, L.L. Revisiting "big ideas in services marketing” 30 years later. J. Serv. Mark. 2016, 30, 3-6. [CrossRef]

65. Oliver, R. Value as excellence in the consumption experience. Consum. Value A Framew. Anal. Res. 1999. [CrossRef]

66. Afuah, A. Mapping Technological Capabilities into Product Markets and Competitive Advantage: The Case of Cholesterol Drugs. Strateg. Manag. J. 2002, 23, 171-179. [CrossRef]

67. Huber, F.; Herrmann, A.; Morgan, R.E. Gaining competitive advantage through customer value oriented management. J. Consum. Mark. 2001, 18, 41-53. [CrossRef]

68. Van der Haar, J.W.; Kemp, R.G.M.; Omta, O. Creating Value that Cannot Be Copied. Ind. Mark. Manag. 2001, 30, 627-636. [CrossRef]

69. Collier, J.E.; Barnes, D.C. Self-service delight: Exploring the hedonic aspects of self-service. J. Bus. Res. 2015, 68, 986-993. [CrossRef]

70. Oliver, R.L. A Cognitive Model of the Antecedents and Consequences of Satisfaction Decisions. J. Mark. Res. 1980, 17, 460-469. [CrossRef]

71. Oliver, R.L. Measurement and Evaluation of Satisfaction Processes in Retail Settings. J. Retail. 1981, 57, $25-48$. [CrossRef]

72. Loureiro, S.M.C.; Miranda, F.J.; Breazeale, M. Who needs delight? J. Serv. Manag. 2014, 25, $101-124$. [CrossRef]

73. Roberts-Lombard, M.; Petzer, D.J.; Svensson, G.; Sosa Varela, J.C. Customer satisfaction/delight and behavioural intentions of cell phone network customers-An emerging market perspective. Eur. Bus. Rev. 2018. [CrossRef]

74. Batra, R.; Homer, P.M.; Kahle, L.R. Values, Susceptibility to Normative Influence, and Attribute Importance Weights: A Nomological Analysis. J. Consum. Psychol. 2001, 11, 115-128. [CrossRef]

75. French, J.R.P.; Rodgers, W.; Cobb, S. Adjustment as Person-Environment Fit in Coping and Adaptation; Basic Books: New York, NY, USA, 1974; pp. 316-333. [CrossRef]

76. Suck, R. The structure of rating scales. J. Math. Psychol. 2018, 87, 98-107. [CrossRef]

77. Nunnally, J.C. Psychometric theory. Am. Educ. Res. J. 1978, 5, 83. [CrossRef]

78. Fornell, C.; Larcker, D.F. Evaluating Structural Equation Models with Unobservable Variables and Measurement Error. J. Mark. Res. 1981, 18, 39-50. [CrossRef]

(C) 2019 by the authors. Licensee MDPI, Basel, Switzerland. This article is an open access article distributed under the terms and conditions of the Creative Commons Attribution (CC BY) license (http:/ / creativecommons.org/licenses/by/4.0/). 